\title{
Application Of BIM 5D Methodology In The Construction Of A Children's Park
}

Ing. Jorge Arroyo Orozco, Msc., Doménica Rendón González, Ing. Gino Flor Chavez, Msc. and Ing. Sabrina Guerrini Cardona $^{1}$

${ }^{1}$ Universidad de Guayaquil, Ecuador,jorge.arroyoo@ug.edu.ec, domenica.rendong@ug.edu.ec, ginoflorch@ug.edu.ec.

Abstract- This project is based on the planning and control of the progress of the construction of the Children's Park in the Corozal Precinct, to carry out the planning of this work, the information was provided by the district administration of Isisdro Ayora, and after a thorough review, we proceeded to calculate the quantities of work, the analysis of unit prices which was used to develop the budget of the project.

Then the Gantt chart was drawn up using the Ms Project software, which shows us the time it takes to carry out each activity with its cost and resources, after which the valued schedules of the team and staff were made.

To use the BIM 5D methodology, the $3 D$ model was made using the Revit 19 software, after obtaining the 3D model, the other two dimensions are integrated by the Navisworks software, in which we integrate the 3D Model with the Gantt Diagram of the Project, obtaining a Model in 5D.

Finally, a simulation of the progress of the project is made, which reflects the time and cost of the work.

Keywords — planning, BIM, construction, design, engineering.

\section{INTRODUCTION}

In recent decades, the work of engineers has changed dramatically. Papyrus, paper, ink and a simple abacus sheets have been the only materials that engineers and architects have had for many years at the time of design. In this situation, designers are usually like a walking library where they are the only connoisseurs of the project globally but in detail, this often happens in projects where there is the participation of several professionals. At the time of planning, a challenge is presented for designers as the work of different areas of project development must be merged.

With the computer advance in Civil Engineering, it has contributed to a more effective development in constructions, which have allowed to improve both the performance of the equipment; how to minimize the waste of materials thus optimizing the times to perform each of the activities during the execution of the work; being the technological tool CAD (Computer-Aided Design), the first computer revolution in the construction sector that is currently widely used as it facilitates and optimizes the time in the preparation of plans replacing the traditional way of the drawing process using pencil and paper, which allows to identify problems not foreseen in the execution of the project.

Digital Object Identifier (DOI):

http://dx.doi.org/10.18687/LACCEI2020.1.1.57

ISBN: 978-958-52071-4-1 ISSN: 2414-6390
These types of technological advances are those that allow the execution of the works more quickly and efficiently; It is for this reason that the present paper work aims to contribute to the efficiency in the planning and control of progress of works using the second technological revolution that currently has emerged in the construction sector called the BIM Methodology (Building Information Modeling), which consists of the administration of the information during the whole life cycle of the project, that is to say that it contains from the conceptual part, the drawing, development of the same as the quantification of quantities and budgets, in addition it also includes the planning and supervision of the progress of the work; All this is done through a platform consisting of a variety of software that are specially designed to work under this methodology.

\section{LOCATION}

The present Children's Park Construction project is located in the Corozal precinct belonging to the Isidro Ayora district of the Guayas Province.

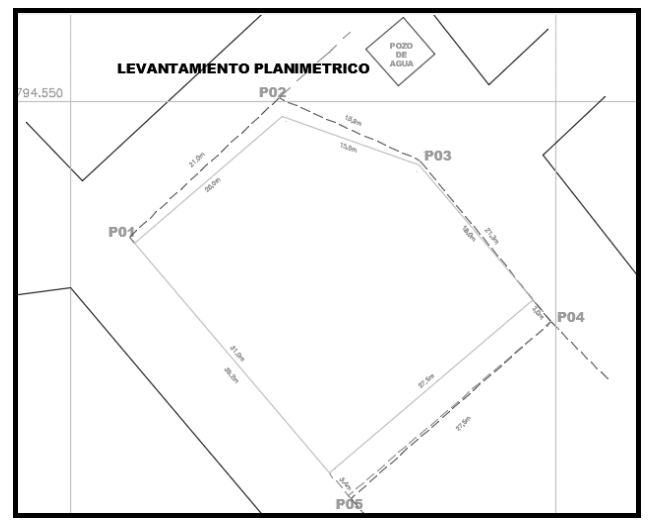

Fig. 1 Planimetric survey map.

TABLE I

HEAD OF PLANNING AND LAND MANAGEMENT OF ISIDRO AYORA DISTRICT ADMINISTRATION.

\begin{tabular}{|c|c|c|}
\hline \multirow{2}{*}{ VERTEX } & \multicolumn{2}{|c|}{ FLAT COORDINATES UTM. WGS84 } \\
\hline & North & East \\
\hline P01 & 9'794.536.2 & $597.656,0$ \\
\hline $\mathrm{P} 02$ & $9^{\prime} 794.550,4$ & $597.671,4$ \\
\hline P03 & $9^{\prime} 794.544,0$ & $597.656,0$ \\
\hline P04 & $9^{\prime} 794.527,5$ & $597.686,0$ \\
\hline $\mathrm{P} 05$ & 9’794.509,4 & $597.678,8$ \\
\hline \multicolumn{3}{|c|}{$\begin{array}{c}\text { Flat coordinates UTM } \\
\text { System: W G S } 84 \\
\text { Zone: } 17 \text { South. }\end{array}$} \\
\hline
\end{tabular}




\section{BASIC CONCEPTS}

1) BIM is the acronym of "Building Information Modeling". [1]

The BIM methodology allows us to generate a virtual model of the construction project in an integral way, with a digital representation of the elements of a work in the different phases of the project and the life cycle; acting as a digital data source where construction information is stored. BIM facilitates those who can affect or be affected by the different activities of the project, storage, consultation and communication of information. [2]

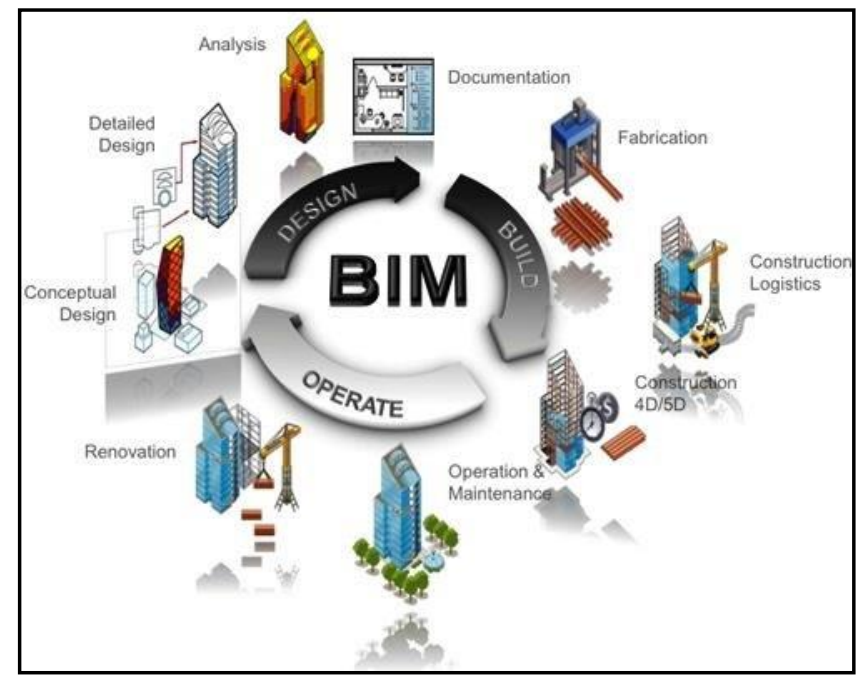

Fig. 2 BIM project life cycle.

\section{2) BIM Software's}

Currently there are some BIM software platforms on the market that are increasingly being implemented, the vast majority of these are intended for architects, engineers; These platforms have several functional tools available for multiple users. [3]

The BIM platforms that we will use in the development of this paper are the following: Revit, and Navisworks.

\section{A. Revit}

It is a design software, particularly designed for BIM, to empower professionals in the construction industry and thus contribute ideas from concept to construction with a coordinated and coherent orientation based on the model.

This platform is a family of integrated products that currently includes Revit Architecture, Revit Structure and Revit MEP in a unique application that includes features of architectural design, structural engineering, mechanical engineering, electrical engineering and construction pipes. [4]
With Revit you can create BIM models that include architecture information, structures that allow you to visualize, communicate and coordinate the project between the specialist and the personnel involved in the project. Likewise, you will be able to achieve a complete and advanced level of documentation of the construction project, achieving together greater efficiency and collaboration between specialties. Maximizing the prediction of performance before construction, with tools that help architects and engineers create architectural, structural analytical models and maintain consistency in each model.

\section{B. Naviswork}

It is a tool that allows us to review the project for the simulation of design and confirmation and validation tests that allows professionals in architecture, engineering; etc., comprehensively review the integrated models and data of the stakeholders to achieve better control over the results of the project. It is presented as different products, each with different applications: Navisworks Freedom, Navisworks Simulate and Navisworks Manage. [5]

\section{Dimensions of THE BIM METHODOLOGY}

\section{A. $B I M 3 D$}

BIM-3D $=$ Architecture + Structure + Facilities. It represents the geometry of the building and is a collection of objects. A perfect way to visualize how the final product will look as we design it. [6]

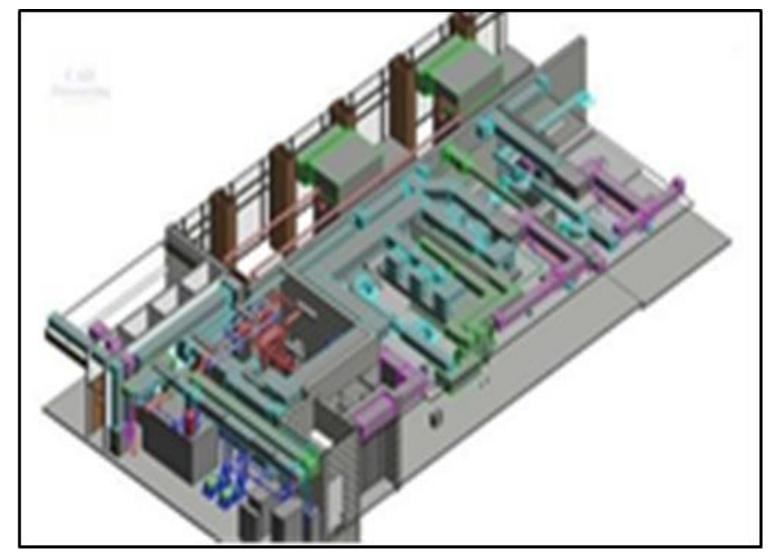

3D

\section{THREE-DIMENSIONAL MODEL}

- GRAPHIC DOCUMENTATION

- GEOMETRIC INFORMATION

- OBJECTS WITH PARAMETERS

-PROJECT VISUALIZATION

Fig. 3 BIM 3D. 


\section{B. $B I M 4 D$}

BIM-4D = BIM-3D + Programming / Time. It is a direct derivation of BIM-3D geometry and an optimization of resources. From the geometry, quantities are extracted, and these quantities are assigned to the resources; then the logical sequence is applied, by creating an optimized program to get the project to flow smoothly. [7]

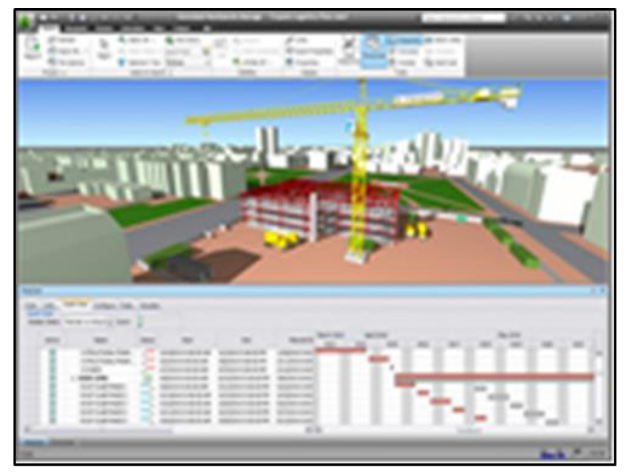

4D

\section{TIME MANAGMENT}

-PROJECT PHASE PLANNING -CONTROL OF EXECUTION DEADLINES

-WORK OPERATIONS OPTIMIZATION

\section{BIM 5D}

Fig. 4 BIM 4D.

BIM-5D = BIM 4D + Cost / Budget. BIM-5D. It is the dimension that allows inserting prices within the BIM model, to have a conception of the economic cost of the work in real time. It is more than model-based estimation. It is a new way of working with the technical groups of the project and owner, covering a large amount of information and experiences in a visually communicative way using $3 \mathrm{D}$ and $4 \mathrm{D}$ models to achieve measurements, correct and coordinate quantities. [8]

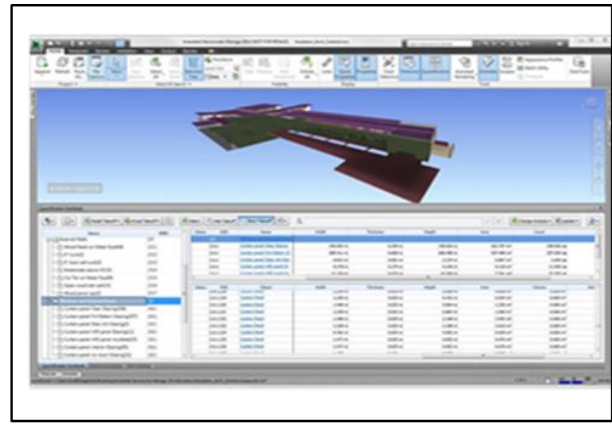

5D

\section{COST MANAGMENT}

-BUDGETS

- EXPENSES CONTROL

-MANAGEMENT OF OFFERS AND CONTRACTS

Fig. 5 BIM 5D.

\section{The Bim Methodology}

The BIM 5D methodology is carried out by developing main tasks; in the first task the 3D BIM 3D modeling is developed in a BIM software in this case we will use Revit; the second task is the preparation of the project budget; in the third task, the BIM 4D model of the project is carried out using a BIM software, for the case study, the work program was developed with the Microsoft Project 2013 software, and the 3D BIM model in the Autodesk Revit 2014 software. The simulation of the BIM 4D model represents the virtual simulation of the construction process of the project. [9]

Finally, we perform task 4, which consists of a BIM 5D model; This is obtained from the unification of the cost estimate and the BIM 4D model. The simulation of the BIM $5 \mathrm{D}$ model represents the simulation of the construction process of each facilities elements, taking into account the position in space, the dimensions of the elements, the time and the cost of construction. For the case study, the BIM 5D model was developed with Autodesk Navisworks software.[10]

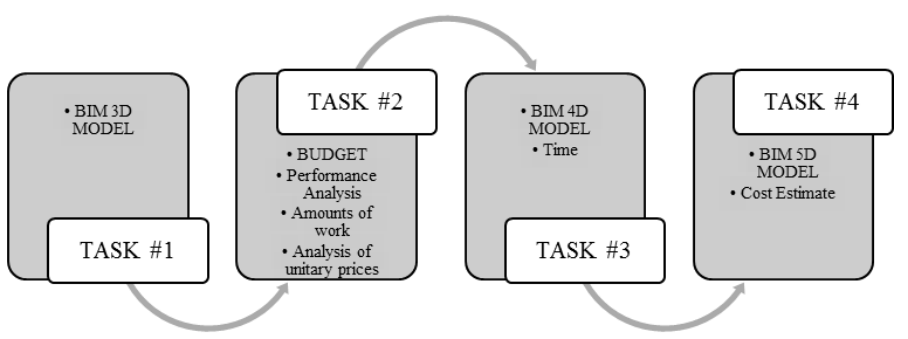

Fig. 6 BIM 5D Methodology.

\section{METhOdOLOGICAL FRAMEWORK}

\section{1) Project Start}

To initiate the project, the plans and technical specifications provided by the City Hall of Isidro Ayora of the Construction of the Children's Park in the Corozal site were reviewed, after having reviewed all the information required to proceed with the calculation of the quantities of work belonging to the different items that contains the budget.

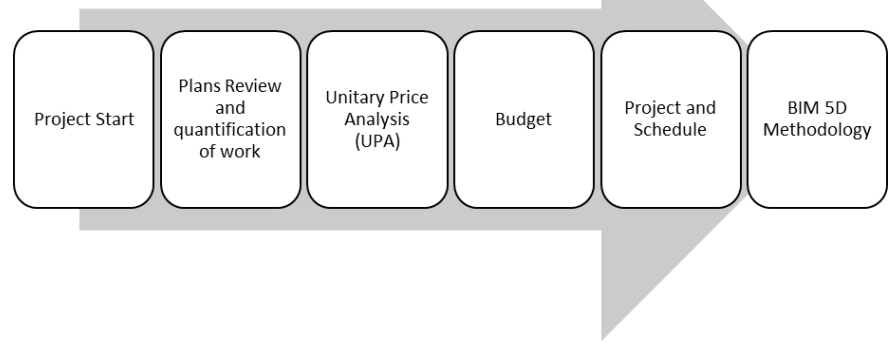

Fig. 7 Work Planning and Control Process. 


\section{2) Project description}

The construction of the Children's Park is located in the Corozal Precint, Isidro Ayora, Guayas Province.

The project is made up of an area of $803.75 \mathrm{~m} 2$, this has perimeter concrete seats, has 4 entrances with doors, 2 areas for children's games such as: monkey bars, slides, see-saws, swings, rocking chairs and structures of concrete, in addition to an area for events with stage, a resting area with metal pergolas with 4 benches surrounded by garden areas.

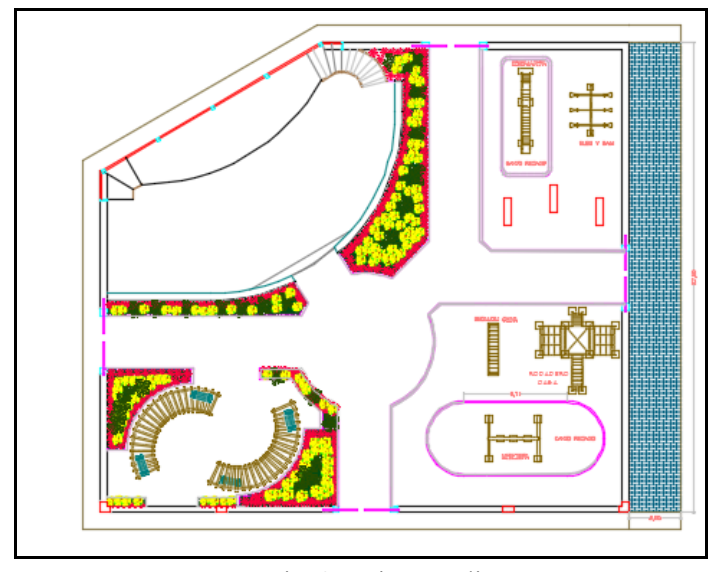

Fig. 8 Project Outline.

\section{3) Planning and Control of Work Progress}

Good planning involves reviewing each of the items with their respective units and being able to group them in an orderly manner and according to their work groups and thus, in turn, be able to calculate the amounts of work with the help of the plans and technical specifications, that the City Hall previously was able to facilitate us, and be able to carry out a good analysis of unit prices taking into account each of the materials and equipment that will be used in the preparation of each work, optimizing all resources to be able to carry out the budget of the work.

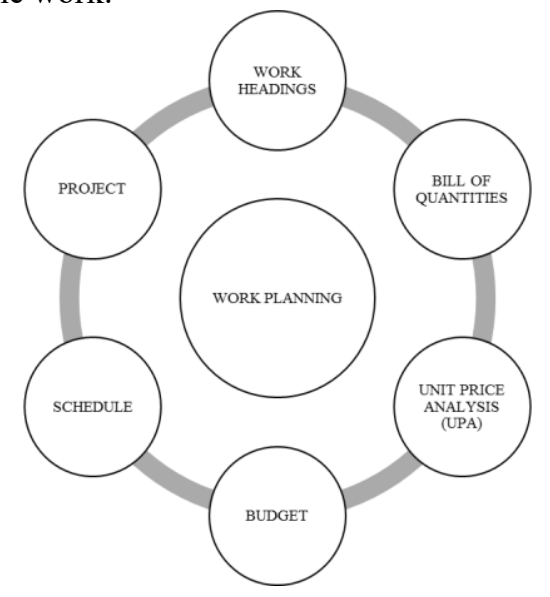

Fig. 9 Work Planning.
We start planning the activities with which it will give a start date to the work and we proceed to carry out the programming using the Project computer tool and software to adjust the items and quantities in a single calendar where we plan to have a vision of their tasks and duration and with what we can count on the execution schedules valued, of equipment and of the personnel, remembering that the GANTT diagram helps us to visualize in chronological order the necessary times to fulfill each one of the planned activities.

The control is carried out with the help of the chronogram performance index and the cost performance index.

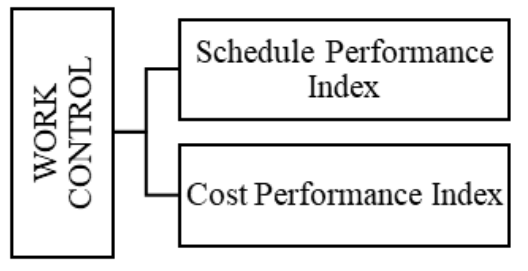

Fig. 10 Work Control.

\section{4) Bim 5d methodology}

To use the BIM 5D methodology it is necessary to make a three-dimensional (3D) model, in this case we use Revit 2019; this is based on architectural and structural plans of the Children's Park Construction project in the Corozal Precinct.

After having the 3D model, the other two dimensions of the methodology must be incorporated; For this we use the Navisworks 2019 software that allows us to integrate a 3D model with a programming made in Project with the respective resources of each item, thus obtaining the fourth 4D dimension that is the estimated times to execute the work, and the fifth 5D dimension Project costs In addition, Navisworks software allows us to perform an animated simulation of the construction process.

\section{Development Of The Topic}

\section{1) Determination Of The Items}

The development of this chapter will be directly linked to the items listed in the following table.

TABLE II

LIST OF ACTIVITIES FOR THE BUDGET

\begin{tabular}{|c|l|c|}
\hline \multicolumn{3}{|c|}{ PRELIMINARY WORKS } \\
\hline 1 & Staking and levelling & $\mathrm{m}^{2}$ \\
\hline 2 & Excavation and eviction & $\mathrm{m}^{3}$ \\
\hline 3 & Compacted fill & $\mathrm{m}^{3}$ \\
\hline \multicolumn{3}{|l|}{ FOUNDATION OF THE ENCLOSURE } \\
\hline 4 & Concrete foundation bed & $\mathrm{m}^{3}$ \\
\hline 5 & $\begin{array}{l}\text { Reinforced Concrete for Plinths F'c }= \\
210 \mathrm{~kg} / \mathrm{Cm} 2 \text { (Includes Steel And Formwork) }\end{array}$ & $\mathrm{m}^{3}$ \\
\hline 6 & Cyclopean concrete $\mathrm{f} \mathrm{c}=180 \mathrm{~kg} / \mathrm{cm} 2$ & $\mathrm{~m}^{3}$ \\
\hline
\end{tabular}




\begin{tabular}{|c|c|c|}
\hline & (includes formwork) & \\
\hline 7 & $\begin{array}{l}\text { Reinforced Concrete For Struts F'c }= \\
210 \mathrm{~kg} / \mathrm{Cm} 2 \text { (Includes Steel And Formwork) }\end{array}$ & $\mathrm{m}^{3}$ \\
\hline 8 & $\begin{array}{l}\text { Reinforced Concrete For Columns F'c }= \\
210 \mathrm{~kg} / \mathrm{Cm} 2 \text { (Includes Steel And Formwork) }\end{array}$ & $\mathrm{m}^{3}$ \\
\hline 9 & $\begin{array}{l}\text { Reinforced Concrete For Benches F'c }= \\
210 \mathrm{~kg} / \mathrm{Cm} 2 \text { (Includes Steel And Formwork) }\end{array}$ & $\mathrm{m}^{3}$ \\
\hline \multicolumn{3}{|c|}{ FOUNDATION OF THE ENTRANCES } \\
\hline 10 & Concrete foundation bed & $\mathrm{m}^{3}$ \\
\hline 11 & $\begin{array}{l}\text { Reinforced concrete for plinths f'c }= \\
210 \mathrm{~kg} / \mathrm{cm} 2 \text { (includes steel and formwork) }\end{array}$ & $\mathrm{m}^{3}$ \\
\hline 12 & $\begin{array}{l}\text { Reinforced concrete for struts f'c }=210 \mathrm{~kg} / \mathrm{cm} 2 \\
\text { (includes steel and formwork) }\end{array}$ & $\mathrm{m}^{3}$ \\
\hline 13 & $\begin{array}{l}\text { Reinforced concrete for columns f'c }= \\
210 \mathrm{~kg} / \mathrm{cm} 2 \text { (includes steel and formwork) }\end{array}$ & $\mathrm{m}^{3}$ \\
\hline 14 & $\begin{array}{l}\text { Reinforced concrete for beam f'c }=210 \mathrm{~kg} / \mathrm{cm} 2 \\
\text { (includes steel and formwork) }\end{array}$ & $\mathrm{m}^{3}$ \\
\hline \multicolumn{3}{|c|}{ FOUNDATION OF THE STAGE } \\
\hline 15 & Concrete foundation bed & $\mathrm{m}^{3}$ \\
\hline 16 & $\begin{array}{l}\text { Reinforced concrete for plinths f'c }= \\
210 \mathrm{~kg} / \mathrm{cm} 2 \text { (includes steel and formwork) }\end{array}$ & $\mathrm{m}^{3}$ \\
\hline 17 & $\begin{array}{l}\text { Reinforced concrete for struts } \mathrm{f}^{\prime} \mathrm{c}=210 \mathrm{~kg} / \mathrm{cm} 2 \\
\text { (includes steel and formwork) }\end{array}$ & $\mathrm{m}^{3}$ \\
\hline 18 & $\begin{array}{l}\text { Reinforced concrete for columns f'c }= \\
210 \mathrm{~kg} / \mathrm{cm} 2 \text { (includes steel and formwork) }\end{array}$ & $\mathrm{m}^{3}$ \\
\hline \multicolumn{3}{|c|}{ STAGE } \\
\hline 19 & Compacted fill & $\mathrm{m}^{3}$ \\
\hline 20 & Tile roof & $\mathrm{m}^{2}$ \\
\hline 21 & $\begin{array}{l}\text { Concrete subfloor for stage } \mathrm{f}^{\prime} \mathrm{c}=210 \mathrm{~kg} / \mathrm{cm} 2 \\
\mathrm{~T}=8 \mathrm{~cm}\end{array}$ & $\mathrm{~m}^{2}$ \\
\hline 22 & Stage ceramics & $\mathrm{m}^{2}$ \\
\hline \multicolumn{3}{|c|}{ WALLS AND PLASTER } \\
\hline 23 & Precast concrete block walls $(\mathrm{T}=10 \mathrm{~cm})\}$ & $\mathrm{m}^{2}$ \\
\hline 24 & Plastered with mortar 1-3 & $\mathrm{m}^{2}$ \\
\hline 25 & Plastered Edges & $\mathrm{m}$ \\
\hline 26 & Decorative Stone & $\mathrm{m}^{2}$ \\
\hline & ELECTRIC INSTALATIONS & \\
\hline 27 & Public lighting point & Pto \\
\hline 28 & Electric power point & Pto \\
\hline 29 & $\begin{array}{l}\text { Low voltage electrical connection }(2 \# 4 / \mathrm{O}- \\
\mathrm{N} \# 1 / \mathrm{O}, \mathrm{T} \# 4)\end{array}$ & $\mathrm{m}$ \\
\hline 30 & Electrical distribution board & $\mathrm{u}$ \\
\hline 31 & Grounded mesh & Pto \\
\hline 32 & THHN feeder (2F\#6+N\#6+T\#8) AWG & $\mathrm{m}$ \\
\hline 33 & THHN feeder (3F\#10+N\#10+T\#12) AWG & $\mathrm{m}$ \\
\hline 34 & THHN feeder (2\#12+T\#14) AWG & $\mathrm{m}$ \\
\hline 35 & Concrete Pass Box $60 \times 60 \mathrm{~cm}$ & $\mathrm{u}$ \\
\hline \multicolumn{3}{|c|}{ LOCKSMITHING } \\
\hline 36 & Front Door (according to design) & $\mathrm{m}^{2}$ \\
\hline 37 & $\begin{array}{l}\text { Metal Posts (according to design) LED } \\
\text { floodlights incluided }\end{array}$ & $\mathrm{u}$ \\
\hline 38 & Metal benches (according to design) & $\mathrm{u}$ \\
\hline 39 & Trash cans & $\mathrm{u}$ \\
\hline \multicolumn{3}{|c|}{ PAINT } \\
\hline 40 & Exterior paint & Glb. \\
\hline \multicolumn{3}{|c|}{ PERGOLA CONSTRUCTION } \\
\hline 41 & Metal pergola (civil works, cover and finishes) & Glb. \\
\hline \multicolumn{3}{|c|}{ SIDEWALKS AND CURBS } \\
\hline 42 & $\begin{array}{l}\text { Concrete curbs for cast pavers on site } 15 \times 20 \\
\mathrm{f}^{\prime} \mathrm{c}=180 \mathrm{~kg} / \mathrm{cm} 2\end{array}$ & $\mathrm{~m}$ \\
\hline 43 & $\begin{array}{l}\text { Concrete curb } 15 \times 20 \mathrm{f}^{\prime} \mathrm{c}=180 \mathrm{~kg} / \mathrm{cm} 2 \\
\text { (includes formwork) }\end{array}$ & $\mathrm{m}$ \\
\hline 44 & $\begin{array}{l}\text { Concrete curb for planters cast on site } 15 \times 20 \\
\mathrm{f}^{\prime} \mathrm{c}=180 \mathrm{~kg} / \mathrm{cm} 2 \text { (includes formwork) }\end{array}$ & $\mathrm{m}$ \\
\hline 45 & $\begin{array}{l}\text { Concrete foundation bed } \mathrm{f}^{\prime} \mathrm{c}=210 \mathrm{~kg} / \mathrm{cm} 2 \mathrm{~T}= \\
10 \mathrm{~cm}\end{array}$ & $\mathrm{~m}^{2}$ \\
\hline 46 & Installation of vehicular decorative pavers & $\mathrm{m}^{2}$ \\
\hline
\end{tabular}

\begin{tabular}{|c|l|c|}
\hline \multicolumn{2}{|c|}{ PLANTERS } \\
\hline 47 & Clay placement & $\mathrm{m}^{3}$ \\
\hline 48 & Sowing land placement & $\mathrm{m}^{3}$ \\
\hline 49 & Supply and planting of ornamental plants & $\mathrm{m}^{2}$ \\
\hline \multicolumn{2}{|c|}{ GAMES SUMINISTRATION } \\
\hline 50 & Monkey bars & $\mathrm{u}$ \\
\hline 51 & See-saw & $\mathrm{u}$ \\
\hline 52 & Slide & $\mathrm{u}$ \\
\hline 53 & Rocking chairs & $\mathrm{u}$ \\
\hline 54 & Concrete structure games & $\mathrm{u}$ \\
\hline 55 & Plastic house with slide & $\mathrm{u}$ \\
\hline \multicolumn{2}{|c|}{ MISCELANIOUS } \\
\hline 56 & Work sign & $\mathrm{u}$ \\
\hline 57 & Safety equipment & $\mathrm{u}$ \\
\hline 58 & Cellar & $\mathrm{u}$ \\
\hline 59 & Work cleaning \\
\hline
\end{tabular}

\section{RESULTS ANALYSIS}

\section{1) Project Modeling}

To develop a BIM 3D model, we used the software Revit 2019, based in the logical programmed sequence of Project.

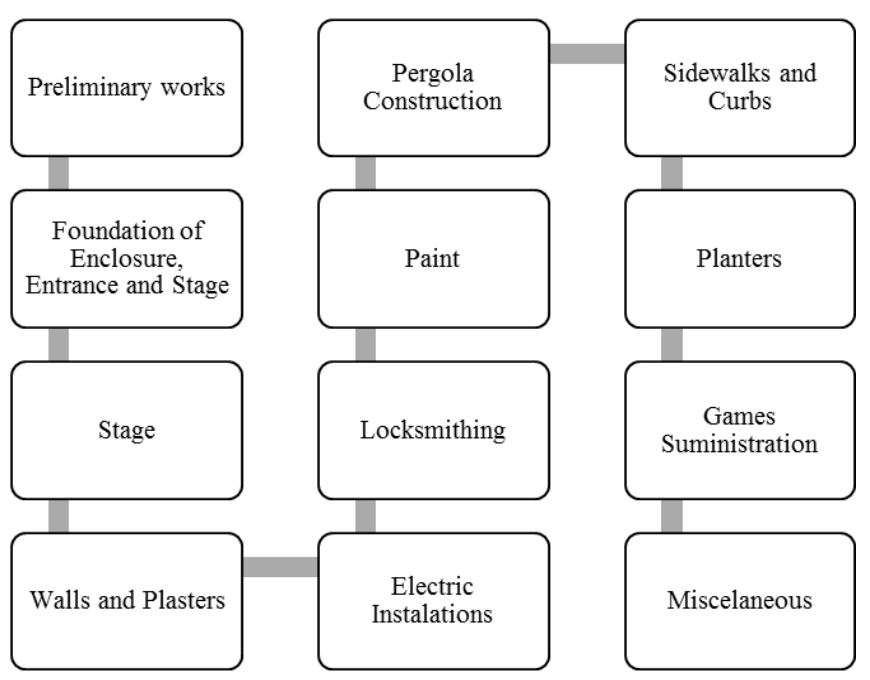

Fig. 11 BIM Modeling of the project.

$18^{\text {th }}$ LACCEI International Multi-Conference for Engineering, Education, and Technology: "Engineering, Integration, and Alliances for a Sustainable Development" "Hemispheric Cooperation for Competitiveness and Prosperity on a Knowledge-Based Economy", 27-31 July 2020, Virtual Edition. 


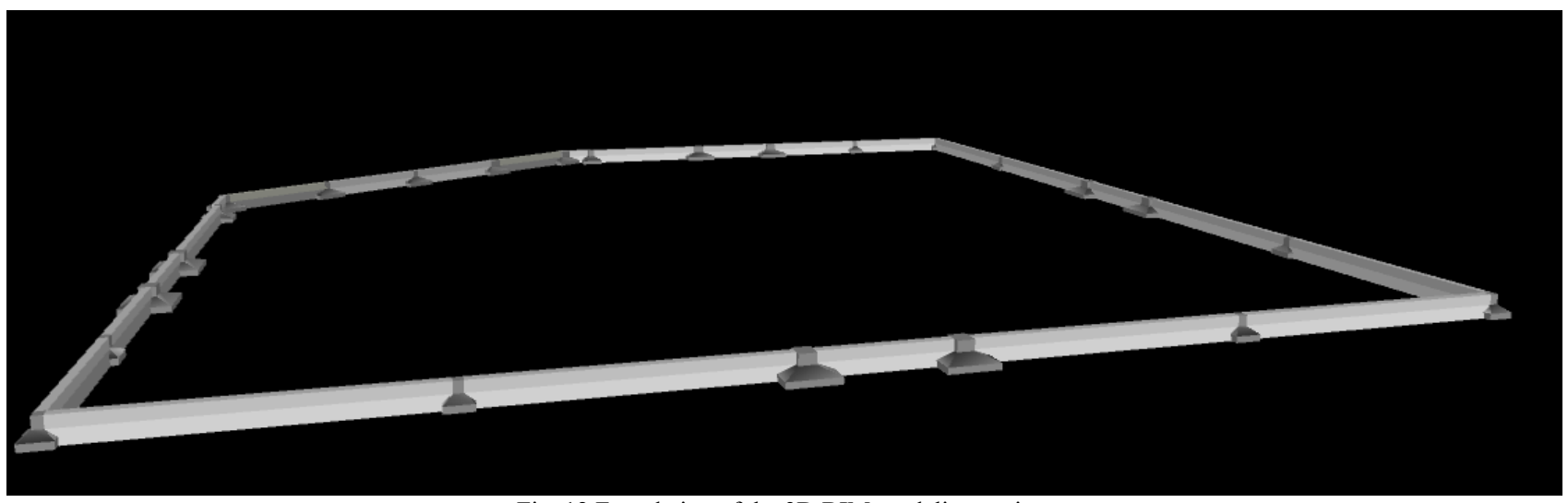

Fig. 12 Foundation of the 3D BIM modeling project

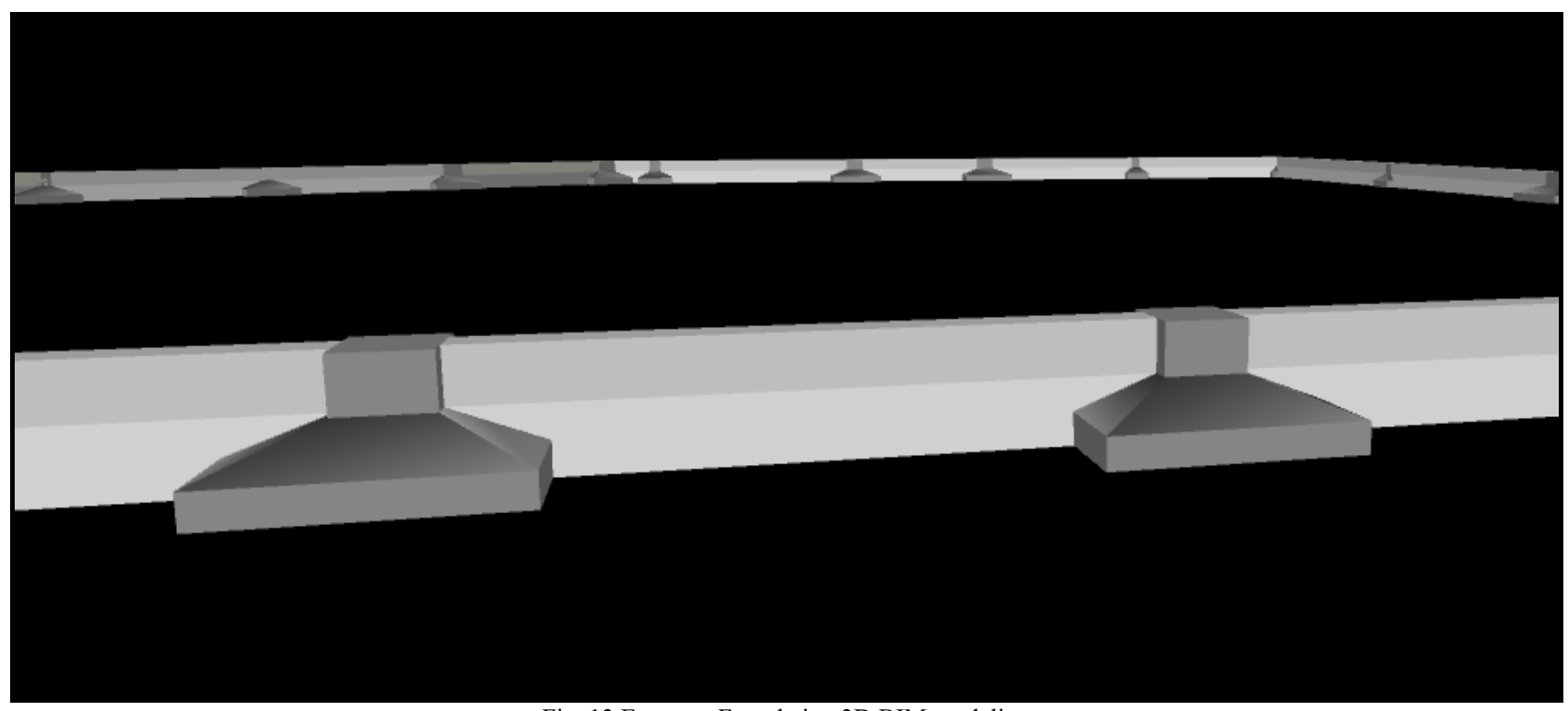

Fig. 13 Entrance Foundation 3D BIM modeling

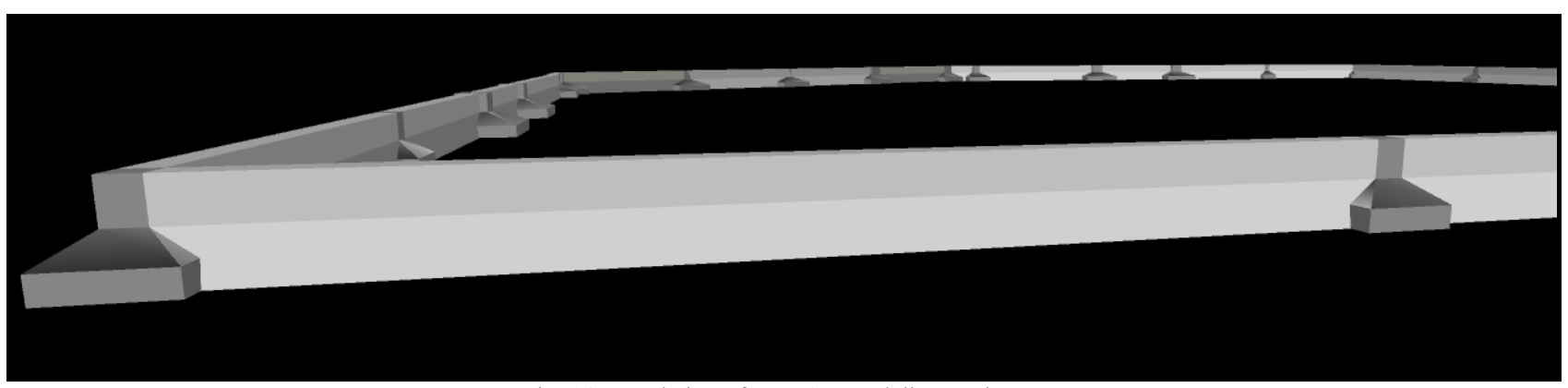

Fig. 14 Foundation of BIM 3D modeling enclosure 


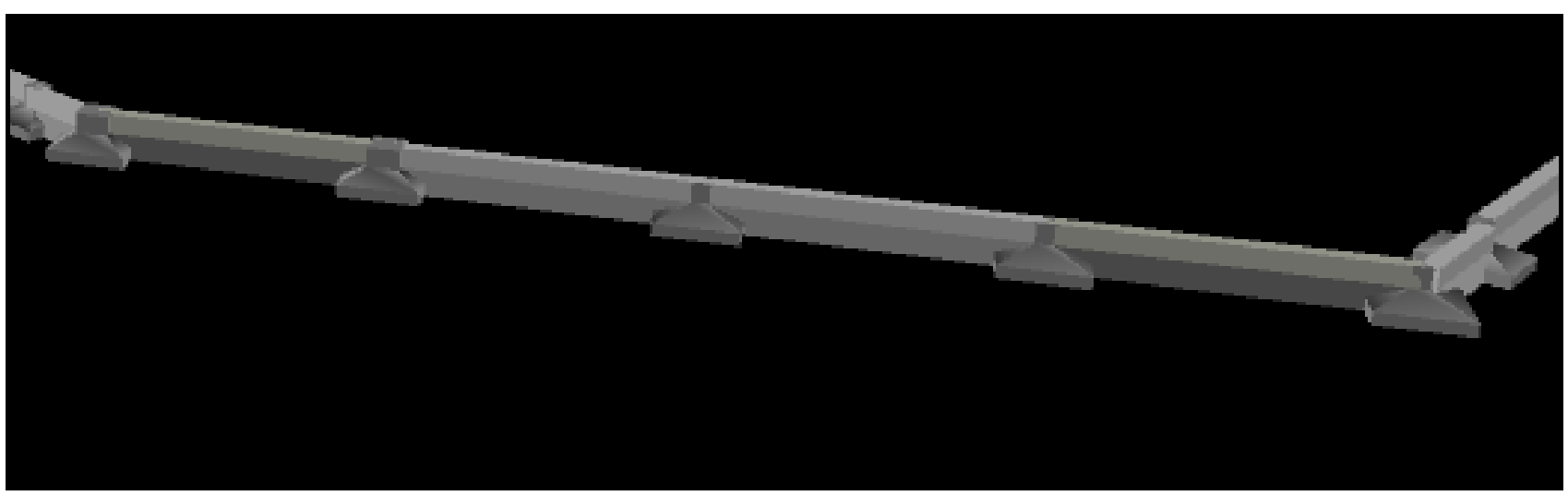

Fig. 15 Foundation of BIM 3D modeling stage

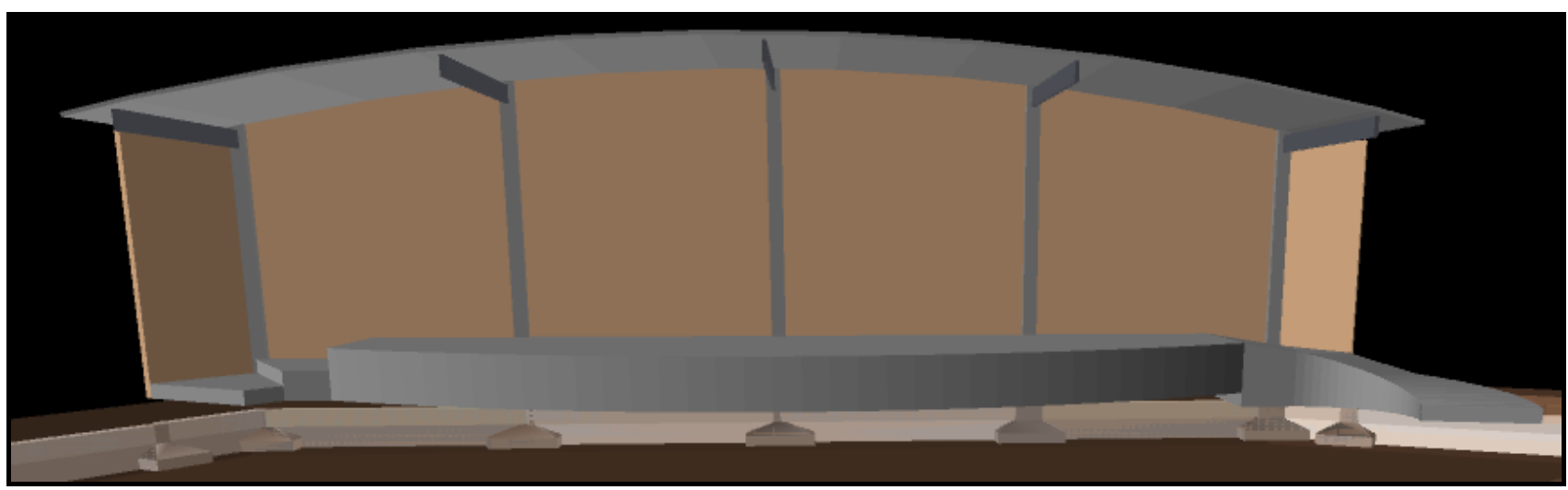

Fig. 16 3D BIM modeling stage

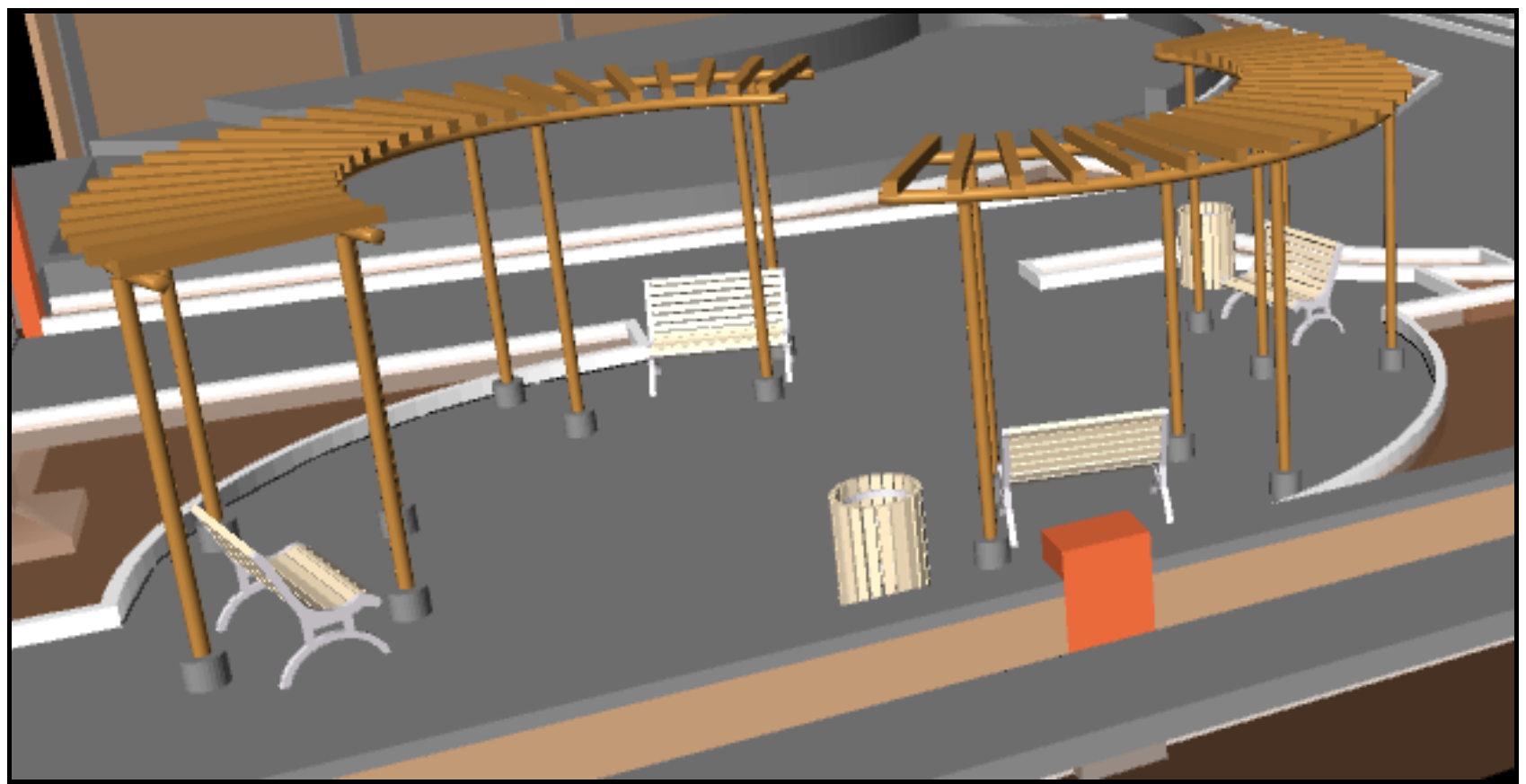

Fig. 17 Pergola, garbage cans, metal benches 3D BIM modeling 


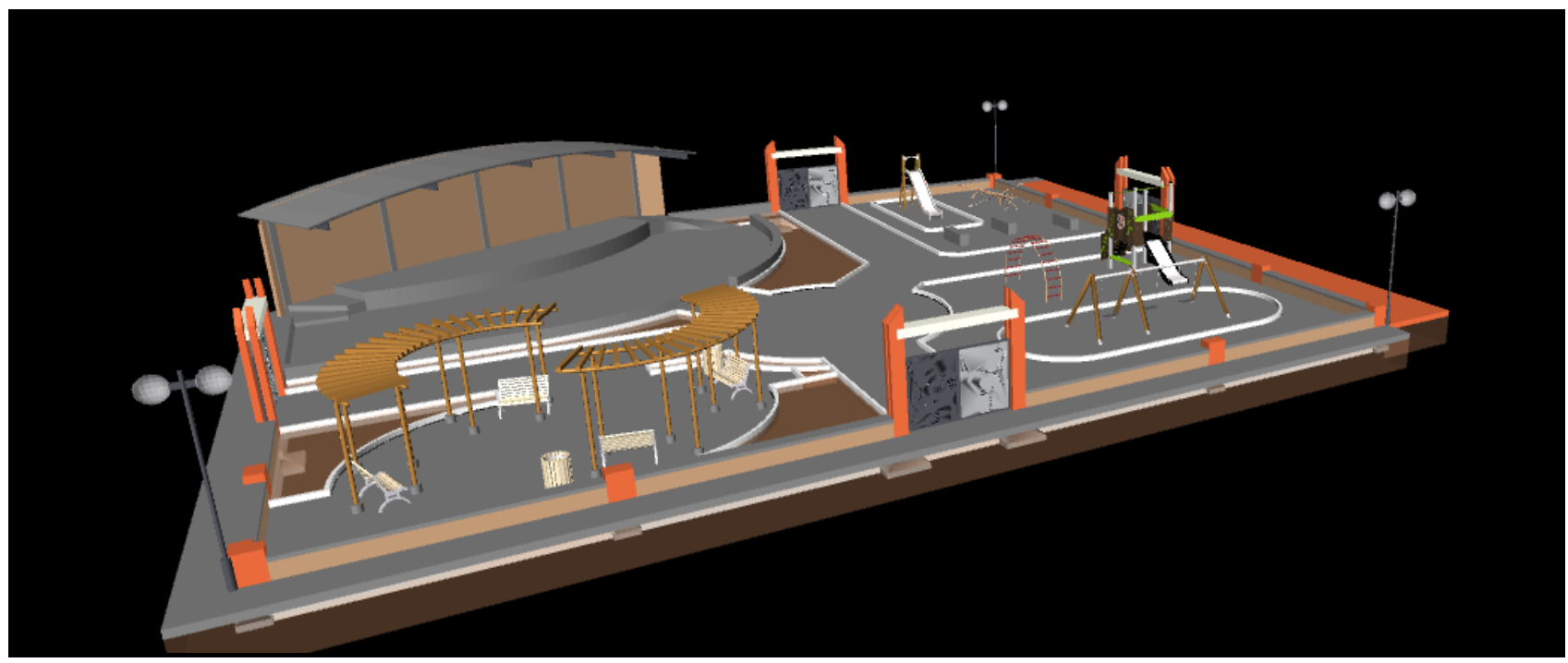

Fig. 18 Final Modeling of the BIM 3D Project

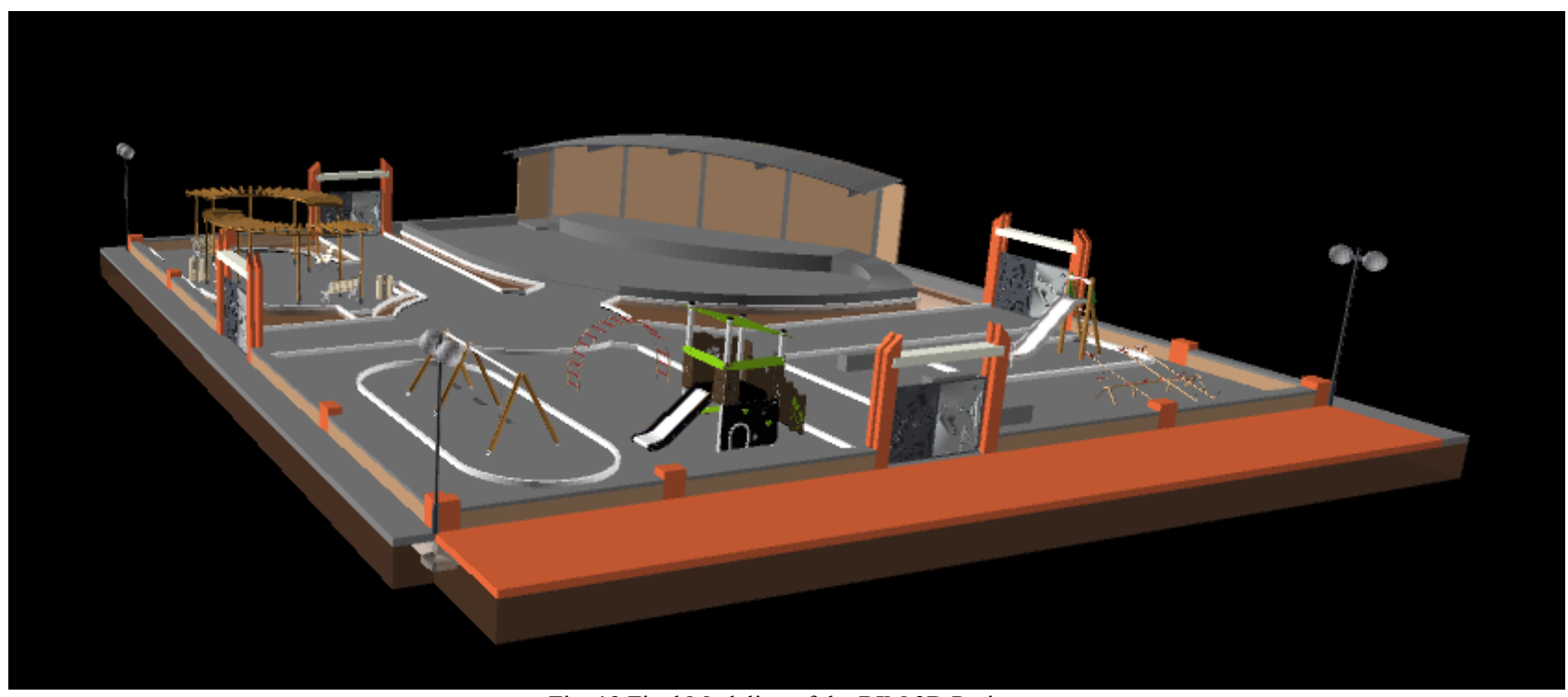

Fig. 19 Final Modeling of the BIM 3D Project

\section{INTEGRATION OF BIM 3D AND PROJECT}

To create the BIM 5D model it is necessary to have the BIM 3D model and the schedule in Project (Gantt Chart), for this we will use the Navisworks software.

As a first step we must add the 3D BIM model in Navisworks. 


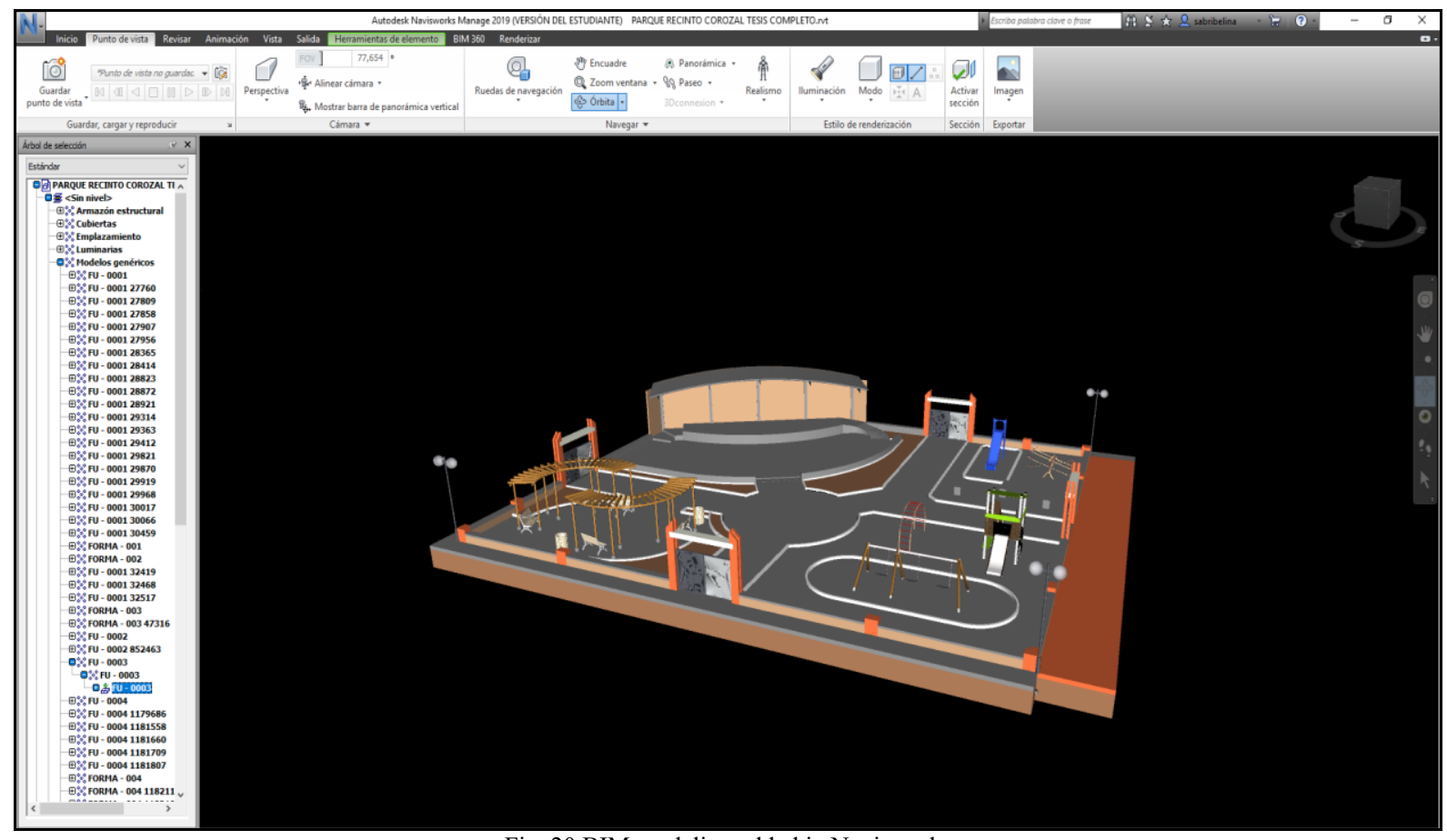

Fig. 20 BIM modeling added in Navisworks

As a second step is to add the Gantt Diagram (Project) this will give us the two missing dimensions to the methodology.

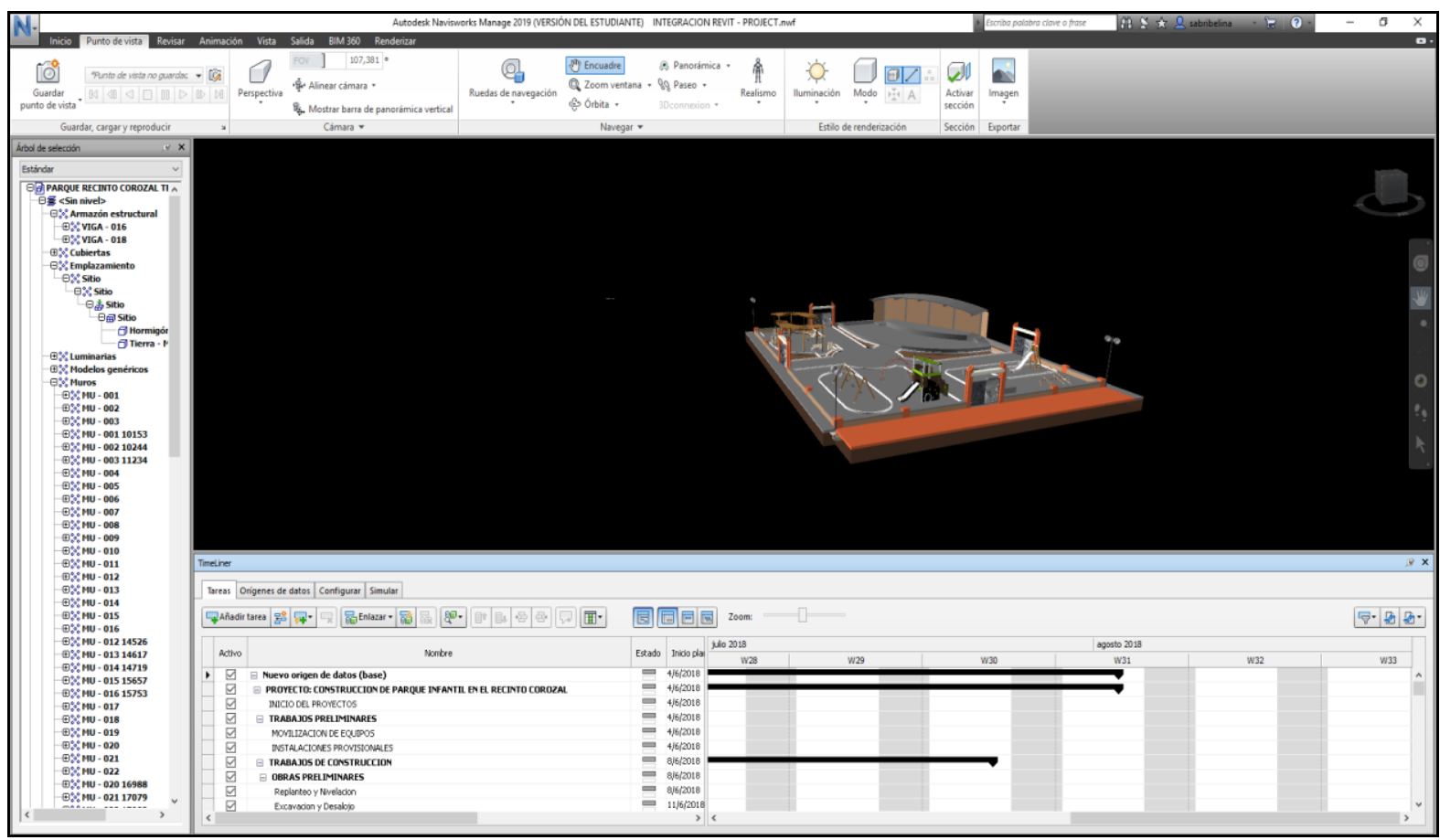

Fig. 21 BIM 3D Model and Project Integration

After having the integration of the 3D BIM Model and the Gantt Diagram (Project), the animated simulation of the construction process is carried out, which will show us the progress of both the model and time and costs, obtaining as final product the BIM 5D. 


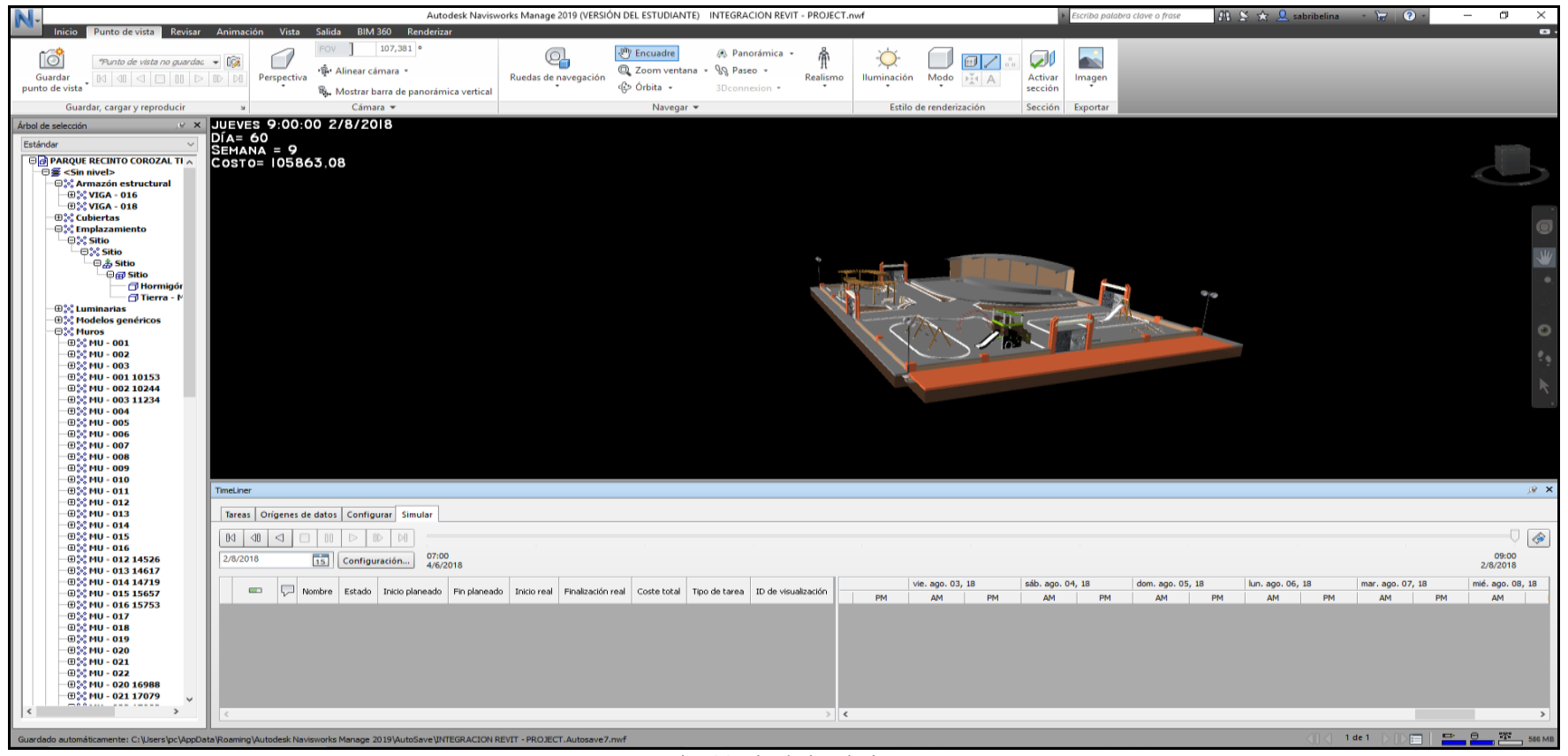

Fig. 22 Final simulation

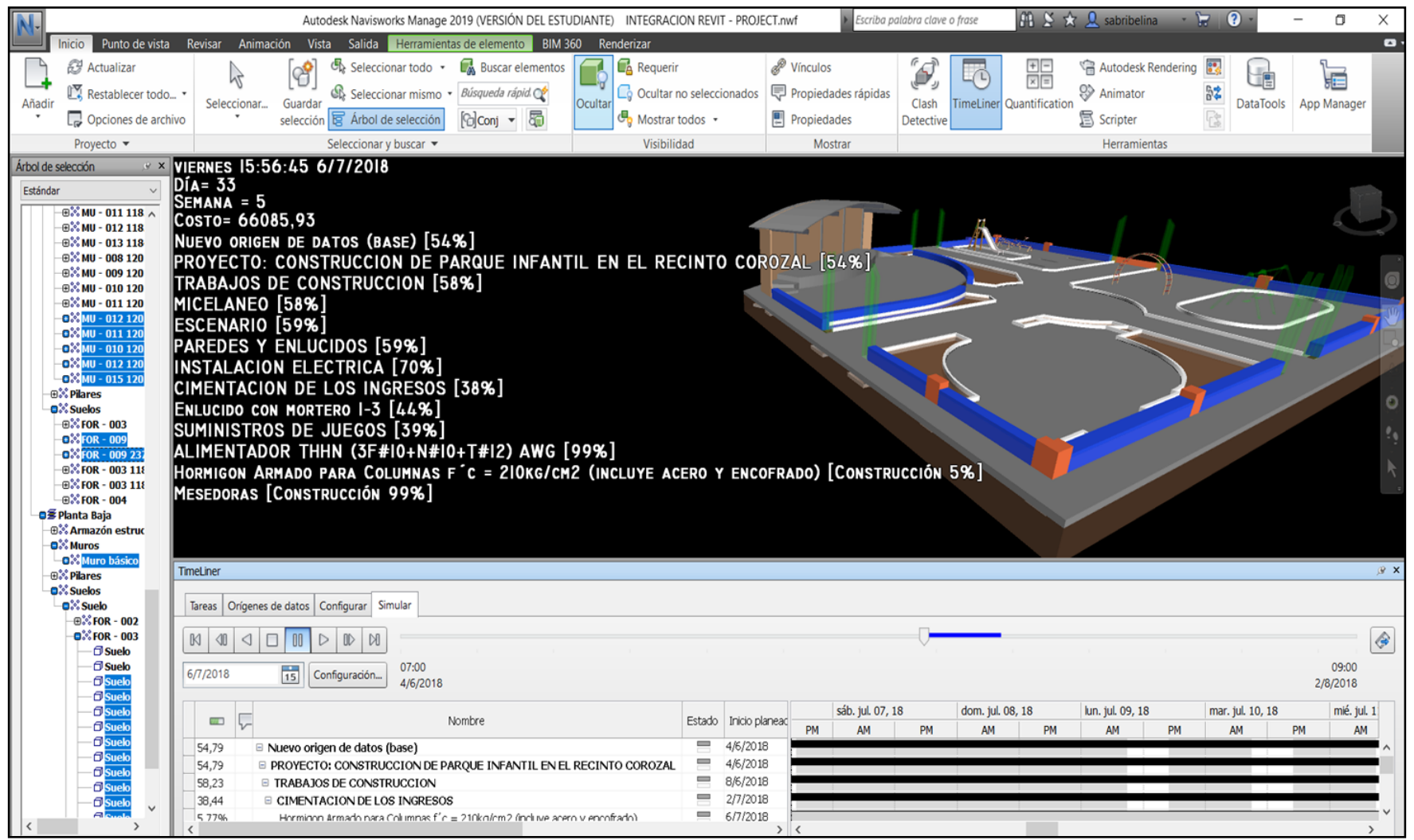

Fig. 23 Final simulation advance control 


\section{CONCLUSIONS}

Through planification and work advance control of the construction of the Children's Park of the Corozal Precinct using the BIM 5D Methodology, we accomplished the proposed objectives, the quantification of amounts of work was realized, unit price analysis to accomplish the project budget; the equipment and manpower schedule was executed, we also developed the Ms Project schedule with the assignation of the costs and the resources of each of the budget activities.

With the application of the BIM 5D methodology, it is easier to realize the planning and work control, because the BIM Model has all the information of the project; thus, the 3D model of the time and cost estimates of the project.

\section{RECOMMENDATIONS}

The use of BIM 5D Methodology in projects, since this methodology provides the builder an optimization of time and resources with a larger organization thus having a more accurate and precise vision of the project thus avoiding future constructive errors at the time of execution.

\section{REFERENCES}

[1] Coloma, E. (2008). Introducción a la Tecnología BIM

[2] Porras, H., Sánchez, O., \& Galvis, J., (2015). Metodología Para La Elaboración De Modelos Del Proceso Constructivo 5d Con Tecnologías "Building Information Modeling"

[3] Eastman, C., Teicholz, P., Sacks, R. \& Liston, K. (2008). BIM Handbook

[4] Autodesk ${ }^{\circledR}$ (2018). BIM for the Building Lifecycle.

[5] Rodríguez, E. (2012). El Tiempo Añadido Al Modelado De Información De Construcción.

[6] Aldo, M., \& Gonzalez, F. (2014). Métodos De Planificación Y Control De Obras: Del Diagrama De Barras Al BIM.

[7] Associated General Contractors of America. (2005). The Contractor's Guide to BIM, 1st ed. AGC Research Foundation, Las Vegas, NV.

[8] Azhar, S., Nadeem, A., Mok, J., \& Leung, B. (2008). Building Information Modeling (BIM): A New Paradigm For Visual Interactive Modeling And Simulation For Construction Projects.

[9] Smith, P. (2014). BIM Implementation-Global Strategies.

[10]Smith, P. (2014). BIM \& The 5D Project Cost Manager.

ORCID iD

Jorge Arroyo Orozco

https://orcid.org/0000-0002-4785-368x

Doménica Rendón González

https://orcid.org/0000-0002-1702-1321

Gino Flor Chavez

https://orcid.org/0000-0002-7838-8450 